Europeanization Through EU External Agreements and the Issue of "Constitutional Identity": The Case of the EU-Armenia CEPA

Author(s): Anna Khvorostiankina

Source: Kyiv-Mohyla Law and Politics Journal 4 (2018): 15-52

Published by: National University of Kyiv-Mohyla Academy

http://kmlpj.ukma.edu.ua/ 


\title{
Europeanization Through EU External Agreements and the Issue of "Constitutional Identity": The Case of the EU-Armenia CEPA
}

\author{
Anna Khvorostiankina \\ National University of Kyiv-Mohyla Academy, \\ Department of Legal Philosophy and Constitutional Law \\ Yerevan Brusov State University of Languages and Social Sciences, \\ UNESCO Chair on Human Rights, Democracy and Political Science
}

\begin{abstract}
Using the concept of "constitutional identity" as a theoretical basis, this article analyses the potential transformative influence of the EU-Armenia Comprehensive and Enhanced Partnership Agreement (CEPA) on the Armenian legal system. In particular, the author focuses on the Agreement's capacity to stimulate the implementation of the EU's "common values" and transpose the norms, general principles, and methodological approaches of EU law into the domestic legal order. It is argued that this potential depends on two elements of the "constitutional identity" of the Armenian legal order: its axiological core and its openness to external influences.
\end{abstract}

Key Words: Europeanization, EU common values, principles of EU law, legislative approximation, legal reforms, constitutional identity, CEPA, Armenia.

\section{Introduction}

Regardless of its frequent application in legal and political discourses, "constitutional identity" remains a vague and ambiguous concept with no precise definition. ${ }^{1}$ One of

$1 \quad$ Michel Rosenfeld opens his chapter "Constitutional Identity" in The Oxford Handbook on Comparative Constitutional Law with the statement that "Constitutional identity" is an essentially contested concept as there is no agreement over what it means or refers to" (Michel Rosenfeld, "Constitutional Identity," in The Oxford Handbook on Comparative Constitutional Law, edited by Michel Rosenfeld and András Sajó (Oxford: Oxford University Press, 2012), 756). See also, for example: Alejandro Saiz Arnaiz and Carina Alcoberro Llivina, "Why Constitutional Identity Suddenly Matters: A Tale of Brave States, a Mighty Union and Decline of Sovereignty," in National Constitutional Identity and European Integration, edited by Alejandro Saiz Arnaiz and Carina Alcoberro Llivina (Antwerp: Intersentia, 2013), 1-3; Jose Luis Marti, "Two Different Ideas of Constitutional Identity: Identity of the Constitution v. Identity of the People," in National Constitutional Identity and European Integration, edited by Alejandro Saiz Arnaiz and Carina Alcoberro Llivina (Antwerp: Intersentia, 2013), 18; Anna Śledzińska-Simon, 
the domains where this concept is usually applied is the area of interrelations between the supranational legal order of the European Union (EU) and the domestic legal orders of its Member States. Both the Court of Justice of the EU (CJEU) and national constitutional courts employ it in their argumentation. While the former contributes to the creation of European constitutional identity through strengthening the valuebased core of the EU's legal order and developing its fundamental principles, the latter tend to defend national constitutional identities, establishing the limits for the further Europeanization of their domestic legal orders. ${ }^{2}$

Building upon case-law created in a specific "European" context, in my research I argue that the concept of "constitutional identity" can be applied not only to characterize the relations between the supranational (EU) legal order and the legal orders of the Member States, but also to assess the potential and explain the dynamics of the "Europeanization" of the legal systems beyond the EU borders, in particular through EU external agreements with third countries. The research is designed as a case study and focuses on the recently concluded EU-Armenia Comprehensive and Enhanced Partnership Agreement (CEPA).

For the purposes of this study, I view "constitutional identity" as a set of characteristics of a legal order, in particular: (1) its axiological core and (2) its relations with other legal orders.

The axiological core of a legal order finds its legal reflection in the so-called identity of a constitution. It can be understood as a system of fundamental principles and values enshrined in the constitution and defining its specific nature. The identity of a constitution is closely interrelated with the dialogically and consciously constructed constitutional identity of a people (or imagined political community) built through political discourse. Sociologically, both depend on the constitutional identity of an actual political community, which is characterized by harmony (or disharmony) between what is written in the constitutional text, the constructed identity of the people, and societal constitutional practices. It shows whether a society is a political community identifying itself with declared constitutional foundations or whether it exists separately in a "parallel world" of its own values and practices. The particularities of interrelations between the legal, political, and sociological dimensions of "constitutional identity" as

"Constitutional Identity in 3D: A Model of Individual, Relational, and Collective Self and its Application in Poland," International Journal of Constitutional Law 13.1 (2015): 124, accessed December 14, 2018, https://doi.org/10.1093/icon/movoo7. Moreover, some authors doubt this concept "is indeed a distinctive phenomenon worthy of its own conceptual class," underlining that it "remains underspecified and difficult to distinguish from related phenomena" (Tommaso Pavone, "Constitutional Identity: An Overview and Some Conceptual Concerns," April 23, 2014, accessed December 14, 2018, https://scholar.princeton.edu/sites/default/files/ tpavone/files/jacobsohn-_constitutional_identity_critical_review.pdf). 
an axiological core of the legal order are determined by the dynamics of change within each of the said dimensions.

The second characteristic forming the "identity" of a given constitutional order determines its relations with other legal orders (international, supranational, subnational, foreign) and the level of its openness to external influences. This characteristic finds its reflection in domestic constitutional law and legal practices.

Employing the concept of "constitutional identity" as a basis of its theoretical framework, this study analyses the potential transformative influence of CEPA on the Armenian legal system. In particular, it focuses on the Agreement's capacity to stimulate the implementation of EU "common values" and transpose the norms, general principles, and methodological approaches of EU law into the Armenian legal order. After introducing the theoretical framework of the research, I briefly characterize the Agreement as the legal basis of EU-Armenia relations. The article then proceeds with an analysis of the issue of "common values," focusing on CEPA instruments of their promotion and their reflection in the domestic legal order. Subsequently, the issue of legal approximation is discussed. I focus on CEPA mechanisms of the legislative approximation stricto sensu, Europeanization through the transposition of the general principles and methodological approaches of EU law into the domestic legal order, and the potential role of the judiciary in these processes.

\section{1. "Constitutional Identity" and the Processes of Europeanization and Regional Integration ${ }^{3}$}

In international academic literature there is no uniform definition of "constitutional identity"; nor is there a clear understanding of who the subject or the bearer of these characteristics is (the constitution as a text? A state? The people?) The context of the application of this concept in judicial argumentation is also varied. As Anna Śledzińska-Simon shows, the concept is mainly applied: "(i) in decisions concerning the legitimacy of constitutional amendments; (ii) in decisions concerning the legitimacy of constitutional migration and engaging in a dialogue between various courts; and (iii) in decisions concerning integration within a supranational organization." ${ }^{4}$ As one can note, in the classification of cases offered by Śledzińska-Simon, the first group of cases focuses on specific "internal" features of a constitutional order (usually reflected in the provisions of a constitution that cannot be [easily] changed), while two other groups deal with the interrelation of a national constitutional order with other legal orders (foreign — in the second group, and supranational — in the third). ${ }^{5}$

The theoretical framework of the article builds upon the revised version of an earlier conference paper published as: Anna Khvorostiankina, “'Constitutional Identity' in the Context of Post-Soviet Transformation, Europeanization and Regional Integration Processes (the Case of Armenia)," Armenian Journal of Political Science 1.6 (2017): 45-80.

4 Śledzińska-Simon, “Constitutional Identity in $3 \mathrm{D}$," 128.

5 Śledzińska-Simon calls these three contexts the "3D model" of constitutional identity comprising simultaneously three dimensions of self — "the individual self, the relational self 
An analysis of the case-law of domestic constitutional courts allows for stating that the third group can be widened to also include decisions concerning other advanced (non-membership) relations between the EU and third countries. The same context can also potentially stimulate the development of the case-law of the second group: in judicial argumentation in countries that are EU partners there is a tendency to refer to the case-law of the Court of Justice of the EU (CJEU) as foreign legal material.

What is common to all three categories of cases is the recognition of the existence of a certain fundamental [value-based] core of a constitutional order, which is to be preserved (from internal change in the first group of cases or possible external influence in the second and third groups), or the "commonality" with which the core of another (EU) legal order serves as a factor legitimizing legal borrowings, legal integration, or the Europeanization of a third country legal system (in the second and third groups of cases). Arguably, to enable legal borrowings, full integration or Europeanization resulting from advanced relations with the EU, the mere recognition of the "commonality" of the fundamentals of legal orders is not enough: there should be specific channels (formal or informal) allowing the domestic legal order to "open up" to the influences of foreign or supranational legal orders. Therefore, to assess the potential transformative influence of the EU on the legal order of a third country it is appropriate to analyze together two elements of its "constitutional identity" - its axiological core and its openness to external influences.

\section{Constitutional Identity as the Axiological Core of a Legal Order}

According to one of the approaches widely accepted in international scholarship, the concept of "constitutional identity" is understood as the identity of a constitution. ${ }^{6}$ The latter, in its turn, is defined as a set of specific characteristics - "constitutive, or essential, or definitional core" 7 - which "makes of that constitution that constitution." 8

Interestingly, these characteristics may comprise both the most important "values, principles, and rules" which create the basis of the constitutional order and are unchangeable (or "eternal"), ${ }^{9}$ and those provisions that make one constitution

and the collective self” (see Śledzińska-Simon, “Constitutional Identity in $3 \mathrm{D}$," 128).

6

See, for example: Marti, “Two Different Ideas of Constitutional Identity”; Pietro Faraguna,

"Constitutional Identity in the EU—A Shield or a Sword?," German Law Journal 18.7 (2017):

1617-40; Śledzińska-Simon, “Constitutional Identity in 3D."

7 Marti, "Two Different Ideas of Constitutional Identity," 22.

8 Marti, "Two Different Ideas of Constitutional Identity," 19.

9 In German constitutional law, for example, the provisions which are unamendable under the "eternity clause" of Art. 79 (3) of the Basic Law are understood as the "identity" of the constitution (see: Monika Pilsen, "Constitutional Identity, Unconstitutional Amendments and the Idea of Constituent Power: The Development of the Doctrine of Constitutional Identity in German Constitutional Law," I*CON 14 (2016): 412). Formal unamendability, however, is not a decisive feature of the constitutional "core." As Marti observes, it can be changed 
significantly different (or distinguishable) from the rest. ${ }^{10}$ P. Faraguna terms the first group of provisions as "constitutional identity despite difference," and the second - as "constitutional identity as difference." 11 Whereas the first group is based on universal values, the second protects particularistic ones. As a consequence, the first group of provisions is practically the same for all European countries (in fact, they constitute "common constitutional traditions" as one of the sources of EU law). ${ }^{12}$ The values underlying such traditions are embodied in Art. 2 of the Treaty on the European Union (TEU), while particularistic values are arguably protected by Art. 4 (2) TEU stating that the Union shall respect Member States' "national identities, inherent in their fundamental structures, political and constitutional."13

Importantly, even within the $\mathrm{EU}$, the perception and practice of fundamental values may differ in different legal orders. ${ }^{14}$ The question is, however, what are the limits for these deviations when it comes to the implementation of "common" or "shared" EU values ${ }^{15}$ and what standards under this pluralistic approach should the EU apply to third countries, in particular, under bilateral agreements.

The second common understanding of constitutional identity refers to the "constitutional identity of the people" (or "political community"). Marti observes that there are at least three possible approaches to this version of "constitutional identity": (1) national identity reflected in the constitution, (2) identity of the people constituted by the constitution (constitutional subject) and (3) the identity of the people as both the author (constitutive authority) and the subject of a constitution. ${ }^{16}$ Regardless of the

in principle, but such change will be much more significant than "regular" constitutional amendments - they will reflect shifts of revolutionary importance (Marti, "Two Different Ideas of Constitutional Identity," 24).

10 These may be historically or culturally rooted provisions. For example, in the case of Armenia, such specific provisions are Article 18 regulating the status of the Armenian Apostolic Church and Article 19 stressing ties with the Diaspora (The Constitution of the Republic of Armenia of 5 July 1995, with the amendments of 2005 and 2015, accessed June 30, 2017, http://www. parliament.am/legislation. php?sel=show\&ID=5805\&lang=eng).

11 Faraguna, “Constitutional Identity in the EU," 1622.

12 See, among others: Faraguna, "Constitutional Identity in the EU," 1632; Marti, "Two Different Ideas of Constitutional Identity," 30.

13 The debate on the meaning of Art. 4 (2) and its correlation with Art. 2 is ongoing in the academic literature.

14 Matej Avbelj, "Pluralism and Systemic Defiance in the EU," in The Enforcement of EU Law and Values: Ensuring Member States' Compliance, edited by Andras Jakab and Dimitry Kochenov (Oxford: Oxford University Press, 2017), 51-52.

The issue became specifically relevant with the Hungarian and Polish rule of law crises. On the necessity of a common understanding and setting 'red lines' for domestic variations see: Armin von Bogdandy et al., "A Constitutional Moment for the European Rule of Law-Upcoming Landmark Decisions Concerning Polish Judiciary," MPIL Research Paper Series 10 (2018): 1-13, accessed May 13, 2018, https://ssrn.com/abstract=3199809. 
differences in meaning, what can be noted in all three approaches is the link between the political community and the constitutional text, ${ }^{17}$ or the link between the values supported by the political community and their reflection in a formal constitution. This link demonstrates that in addition to the formal legal dimension of the constitutional identity as a value-based core of a constitutional order, there is another - political dimension of the same phenomenon. From this perspective, "constitutional identity" is not a static set of provisions or a state of affairs, but a dynamic system of social relations.

Jacobsohn stresses that "a constitution acquires an identity through experience"; constitutional identity "neither exists as a discrete object of invention nor as a heavily encrusted essence embedded in a society's culture, requiring only to be discovered." 18 He then continues stating that:

Identity emerges dialogically and represents a mix of political aspirations and commitments that is expressive of a nation's past, as well as the determination of those within the society who seek, in some ways, to transcend that past. It is changeable but resistant to its own destruction, and it may manifest itself differently in different settings. ${ }^{19}$

Importantly, under this approach, "the people" is not an actual community consisting of real individuals and social groups. As Rosenfeld argues, it is an "imagined," evolving community that "does not correspond to any set of persons crisply delimited in time and space," 20 although "it must channel its manifestations and iterations through persons assembled in plausible even if not actual configurations." ${ }^{21}$

Jacobsohn's definition implies that constitutional identity is, first, consciously constructed and, second, historically rooted. Arguably, in the context of post-Soviet transition, the constitutional courts became one of the most significant "creators" of constitutional identity "carrying out" — as D. Robertson notes — "a quite new type of political function" of "transforming societies" through "spreading the values set out

17 As Rosenfeld, agreeing with Jacobsohn, underlines that "constitutional identity furnishes essential links between the constitution, its environment, and those who launched it as well as those for whom it was intended” (Rosenfeld, "Constitutional Identity," 76o-61).

18 Gary Jeffrey Jacobsohn, “Constitutional Identity,” The Review of Politics 68 (2006): 361.

19 Jacobsohn, "Constitutional Identity," 361.

20 Michel Rosenfeld, "The Constitutional Subject, Its Other, and the Perplexing Quest for an Identity of Its Own: A Reply to My Critics," Cardozo Legal Studies 358 (2012): 13, accessed May 22, 2018, https://ssrn.com/abstract=2021356. 
in the constitution throughout their state and society" 22 and developing the so-called acquis constitutionelle. ${ }^{23}$

Historical legacies as one of the factors shaping constitutional identity lead us to the third dimension of constitutional identity - the sociological one: even if on the level of political discourse the "imagined political community" negates or "seeks to transcend" its past, in reality the culture and mentality of an actual society is significantly more resistant to transformations. In other words, the dynamics of change within three dimensions of constitutional identity—legal, political, and sociological— differ significantly.

Noteworthy, the discrepancy (or "disharmony") between the ideas embodied in the constitution and the social reality, remarkably, is one of the central concepts in Jacobsohn's theory of constitutional identity. Although immanent for all constitutional orders to a certain extent, "disharmony" becomes especially evident in the cases of societies in transition (as those of post-Soviet space) where there is a tension between the "transformation" and "preservation" of specific social values. ${ }^{24}$ In this context, understanding "constitutional identity" as a value-based core of a constitutional order simultaneously finding its reflection in legal, political, and social domains, seems to be a fruitful interdisciplinary (socio-legal) approach allowing for the evaluation of the extent to which values declared in the constitution and promoted as a part of the constitutional identity of the people (often under the influence of external factors or actors) are supported and shared by the society. ${ }^{25}$ Obviously, in order to strengthen the rule of law, democracy, and respect for human rights, it is not enough to declare these values as fundamental in the text of a constitution. Proper implementation in practice

22 David Robertson, The Judge as Political Theorist: Contemporary Constitutional Review (Princeton: Princeton University Press, 2010), 1.

23 "The Continuity of Jurisprudential Lines [of Constitutional Courts] and Accumulation of Constitutional Experience" (Marek Safjan, "Political and Constitutional Courts. A Judge's Personal Perspective," EUI Working Paper Law No. 2008/10, accessed June 17, 2018, http:// cadmus.eui.eu/handle/1814/8101).

In Jacobsohn's words, “[c]onstitutional disharmony creates a need for adaptation and coping with conflict and dissonance, and constitutional identity must be shaped dialogically with a view to overcoming the causes of such disharmony" (Rosenfeld, "Constitutional Identity," 761). According to Vorländer, "Constitutions can only do justice to their central tasks of legitimising and integrating political communities and their institutions if their normative rules and offered meanings are accepted and practiced in the social reality, if communication about fundamental values and patterns of behaviour takes place between the rulers and the ruled" (Hans Vorländer, "Gründung und Geltung: Die Konstitution der Ordnung und die Legitimität der Konstitution," in Geltungsgeschichten: Über die Stabilisierung und Legitimierung institutioneller Ordnungen, ed. Gert Melville and Hans Vorländer (Cologne; Weimar; Vienna: Böhlau, 2002), 256 as cited in: Silke Hensel, Ulrike Bock, Katrin Dircksen and Hans-Ulrich Thamer, ed., Constitutional Cultures: On the Concept and Representation of Constitutions in the Atlantic World (Newcastle upon Tyne: Cambridge Scholars Publishing, 2012), 5). 
is what really matters. ${ }^{26}$ Therefore, the phenomenon of constitutional identity in its sociological dimension is closely intertwined with the phenomenon of constitutional culture $^{27}$ (or in a broader sense-legal culture ${ }^{28}$ ).

What is the link between "constitutional identity" as the axiological core of a constitutional order in its legal, political, and sociological dimensions and the processes of Europeanization?

According to the definition given by C. Radaelli, Europeanization comprises

[the] processes of (a) construction (b) diffusion and (c) institutionalization of formal and informal rules, procedures, policy paradigms, styles, "ways of doing things" and shared beliefs and norms which are first defined and consolidated in the making

26 Comparing more than 100 constitutions, Ginsburg and Versteeg show that countries that explicitly protect such values as the rule of law in their constitutions tend to have a lower level of respect for the rule of law in practice than those that do not include rule of law guaranties in constitutional texts (Tom Ginsburg and Mila Versteeg, "Constitutional Correlates and the Rule of Law," in Constitutionalism and the Rule of Law: Bridging Idealism and Realism, edited by Maurice Adams, Anne Meuwese and Ernst Hirsch Ballin (Cambridge; New York: Cambridge University Press, 2017), 507, 517).

27 As Siegel observes, "constitutional culture" is "[...] an interlocking system of practices, institutional arrangements, norms, and habits of thought that determine what questions we ask, what arguments we credit, how we process disputes, and how we resolve those disputes" (Andrew M. Siegel, “Constitutional Theory, Constitutional Culture," Journal of Constitutional Law 18.4 (2016): 1107). According to Mazzone, "[c] onstitutional culture [...] can be said to include such things as the disposition of regular citizens to recognize and accept that they are governed by a written document, one that creates institutions of government and sets limits on what the government may do; the accepted belief that the governing charter is created by the citizenry; the knowledge that the charter is not timeless, but rather that the citizens may change it or revoke it under certain circumstances; and the understanding that until the charter is changed we are bound by it and required to go along with its ultimate results even though we are free to disagree with them. Constitutional culture also includes the understanding that a constitution unifies a population beyond those in one's immediate sphere of acquaintance such that other people in other places are likewise governed by this written document and that, whatever our other differences, this is something we have in common" (italics added) (Jason Mazzone, "The Creation of a Constitutional Culture," Tulsa Law Review 40.4 (2004): 672). The last element in conjunction with internalized constitutional values, in my view, compose the constitutional identity of an actual political community.

28 In his "Law and Society: An Introduction," L. M. Friedman states that legal culture "determines when, why, and where people use law, legal institutions, or legal process; and when they use other institutions or do nothing"; it "sets everything in motion" and "is an essential variable in explaining the working of law" (cited as in: Roger Cotterrell, Law, Culture and Society: Legal Ideas in the Mirror of Social Theory (London: Routledge, 2006), 86). 
of EU decisions and then incorporated in the logic of domestic discourse, identities, political and public policies. ${ }^{29}$

The concept of "Europeanization" thus covers a set of complex processes of change that transform not only the legislation of a country, but also influence political culture, the legal mentality, and judicial reasoning; empower civil society, and transform relations between the state and an individual. Arguably, the transformative influence may be either directed, initiated, and stimulated by the EU or result from voluntary genuine change initiated on a domestic level, inspired by European models. In both cases, when the changes affect a value system, the values should be internalized and change has to occur in the constitutional identity on the level of the actual society.

\section{1. "Constitutional Identity" and the Vectors of Regional Integration}

The next issue to analyze is whether constitutional identity encompasses orientation towards specific integration projects. On the one hand, the choice of a particular integration project can be influenced by a range of factors - geopolitical, political, and economic. On the other hand, however, in some cases geopolitical orientation may become an element of the constitutional identity enshrined in the constitution or documents of a constituting character (such as declarations of independence) having the status of a constitutional value. Here one can speak about the interplay of the identity of a constitution and that of the people: the people view a specific geopolitical orientation as preferable (or the only one possible); and the constitutional text reflects and protects this value.

In post-Soviet space there are several cases of the recognition of the specific vector of integration as a part of constitutional identity. In particular, in the case of Lithuania, the constitutional prohibition of joining "in any form any new political, military, economic, or other unions or commonwealths of states formed on the basis of the former USSR" 30 became a part of constitutional identity explicitly reflected in the constitutional text. ${ }^{31}$ In Moldova, the Constitutional Court ruled that "orientation towards the European area of democratic values is an element of the constitutional

29 Claudio M. Radaelli, "Whither Europeanization? Concept Stretching and Substantive Change," European Integration Online Papers 4 (2000): 3.

$30 \quad$ Par. 1 of the Constitutional Act of 8 June 1992 "On the Non-Alignment of the Republic of Lithuania with Post-Soviet Eastern Alliances," accessed April 12, 2018, https://e-seimas.lrs.lt/ portal/legalAct/lt/TAD/TAIS.21154?jfwid=1clcwot6i3. According to Art.150 of the Constitution of the Republic of Lithuania, the Constitutional Act is an integral part of the Constitution, English version: https://e-seimas.lrs.lt/rs/legalact/TAD/TAIS.206o72/ (accessed June 30, 2017). Dainius Žalimas, "Eternity Clauses: A Safeguard of Democratic Order and Constitutional Identity," Speech of the President of the Constitutional Court of Lithuania, 2, accessed November 1, 2017, http://www.gjk-ks.org/repository/docs/Speech_of_the_President_of_the_ Constitutional_Court_of_Lithuania_Prof.Dr._Dainius_alimas.pdf. 
identity of the Republic of Moldova." This element, according to the Court, is a defining one: "the process of European integration [...] not only complies with the constitutional identity of the country, any other adverse orientation is unconstitutional a priori." ${ }^{32}$

\subsection{Constitutional Identity as the Openness of a Constitutional Order}

In addition to an axiological basis, constitutional identity also determines the relations of a constitutional order with other legal orders. ${ }^{33}$ In today's realities, national constitutional orders cannot exist in isolation; they are in dialog with international, supranational, subnational, and foreign legal orders. ${ }^{34}$ This dialog results in mutual (although usually asymmetric) transformative influences. The concept of constitutional identity in this case helps to characterize the limits and define the available channels of these possible influences. It indicates the degree of sensitivity and openness of a constitutional order to various types of external influence, in particular, its adaptability to external standards and requirements.

The said external influences may be both formal and informal and may be realized through different "channels" — through formal legal tools provided by national legislation ${ }^{35}$ and/or indirectly through the socialization of the domestic actors involved

32 Judgment on the constitutionality of the Association Agreement between the Republic of Moldova, on the one hand, and the European Union and the European Atomic Energy Community and its Member States, on the other hand, and of Law No.112 of July 2, 2014 on its ratification, English version, accessed November 1, 2017, http://www.constcourt.md/libview. php? $\mathrm{l}=$ en\&idc $=7 \& \mathrm{id}=583 \& \mathrm{t}=/$ Overview $/$ Press-Service/News/The-Association-Agreementbetween-the-Republic-of-Moldova-and-the-European-Union-constitutional. This approach echoes Śledzińska-Simon's theory of constitutional identity as a three-partite self. She, however, differentiates between "horizontal" (foreign) and "vertical" (supranational) relations with “others” (see: Śledzińska-Simon, “Constitutional Identity in $3 \mathrm{D}^{\text {”). Two notes }}$ should be added here: (1) in Śledzińska-Simon's approach the focus is made on the selfperception of a subject (individual, relational, or collective selves), while in the approach proposed in this article openness towards interactions with others, the level of sensitivity or adaptability to their influences, and available tools channeling influence are underlined; (2) the separation of "vertical" interactions is valid in the relations between the EU and its Member States and is significantly less evident in the case of relations with third countries.

34 As Armin von Bogdandy notes in relation to the contemporary notion of legal pluralism and the interaction of legal orders, "any given constitution does not set up a normative universum anymore but is, rather, an element in a normative pluriversum" (Armin von Bogdandy, "Pluralism, Direct Effect, and the Ultimate Say: On the Relationship Between International and Domestic Constitutional Law," International Journal of Constitutional Law 6.3-4 (2008): 401). To provide some examples, one can refer to Art. 5(3) of the Constitution of Armenia setting out a hierarchy of legal norms and providing that "In case of conflict between the norms of international treaties ratified by the Republic of Armenia and those of laws, the norms 
in law-making and law-applying (first of all, judicial) activities. Consequently, the obstacles for the effective interplay of the national constitutional order with other legal orders may be created either directly by a constitution or constitutional legislation, or indirectly by domestic actors. The latter situation is typical for judicial practices in postSoviet countries where constitutional identity is still in the process of formation. On the one hand, there is a tendency for orientation on international legal standards (and there are some legislative "channels" for doing this), following foreign "best practices," and "borrowing" external experience. On the other hand, these processes are hindered by methodological problems caused by the particularities of a legal mentality affected by a positivistic tradition, the lack of relevant information, and a language barrier. ${ }^{36}$

In summary, the relation between the processes of the Europeanization of a third country through agreements with the EU and the constitutional identity of the latter can be characterized as follows. Although an orientation towards integration with the $\mathrm{EU}$ (without membership) in some cases may be encompassed by the value component of constitutional identity, the adaptability of a third country's constitutional order to the requirements of the integration project depends on both its value-based core

of international treaties shall apply"; Art. 81 of the Constitution of the RA stating that "The practice of bodies operating on the basis of international treaties on human rights, ratified by the Republic of Armenia, shall be taken into account when interpreting the provisions concerning basic rights and freedoms enshrined in the Constitution. Restrictions on basic rights and freedoms may not exceed the restrictions prescribed by international treaties of the Republic of Armenia"; Art. 15 of the Judicial Code of the RA of 2007 recognizing the case-law of the ECHR as an official source of law in Armenia. Art. 43 of the Constitution in its version of 1995 stating that the rights and freedoms guaranteed by the Constitution are not exhaustive and a person can have other rights, in particular those guaranteed by international treaties. The Constitutional Court used this constitutional provision as a ground for its arguments confirming the compliance of the obligations deriving from the ECHR with the Armenian Constitution, thus confirming the openness of the Armenian constitutional order to international human rights standards (see par. 13 of Decision DCC-350 of 22 February 2002).

36 Let us consider the practice of the application of the case-law of the ECHR by domestic courts. Although ECHR case-law is recognized as an official source of law in Armenia, judges still face methodological problems while applying it due to the long-lasting domination of legal positivism during the Soviet era (see: Narine Ghazaryan and Anna Hakobyan, "Legislative Approximation and Application of EU Law in Armenia," in Legislative Approximation and Application of EU Law in the Eastern Neighbourhood of the European Union, edited by Peter Van Elsuwege and Roman Petrov (London; New York: Routledge, 2014), 205). These problems are not unique, however: to a certain degree they are typical for post-communist countries (see, for example: Zdeněk Kühn, "The Application of European Law in the New Member States: Several (Early) Predictions," German Law Journal 6.3 (2005): 564; Andriy Meleshevych and Anna Khvorostyankina, "Ukraine," in The European Convention on Human Rights and Fundamental Freedoms in Central and Eastern Europe, edited by Leonard Hammer and Frank Emmert (The Hague: Eleven International Publishing, 2012), 557-96). 
and the level of its openness to external influences (formal and informal). While the former defines the "substance" of adaptation processes, the latter determines their effectiveness and defines applicable mechanisms and tools.

In the following sections of the article the transformative potential of the EUArmenia CEPA will be assessed through the lens of the concept of "constitutional identity." The analysis will start with a brief characterization of the Agreement, addressing its current status, objectives, and legal basis, the context of its conclusion and ratification, as well as its institutional framework.

\section{CEPA: A New Legal Framework of EU-Armenia Relations}

The EU-Armenia Comprehensive and Enhanced Partnership Agreement ${ }^{37}$ was signed on November 24, 2017. After examination by the Constitutional Court of the RA ${ }^{38}$ on March 16, $2018^{39}$ and ratification by the National Assembly (the Parliament of Armenia) on April 11, 2018, ${ }^{40}$ CEPA became an integral part of the Armenian domestic legal system, enjoying supremacy over national laws. ${ }^{41}$ The Agreement is not yet in force

37 Comprehensive and Enhanced Partnership Agreement between the European Union and the European Atomic Energy Community and their Member States, of the One Part, and the Republic of Armenia, of the Other Part (Not Yet in Force), OJ L 23 (January 26, 2018), 4-466, accessed June 15, 2018, https://eur-lex.europa.eu/legal-content/EN/ TXT/?uri=CELEX:22018Ao126(o1)\&qid=152319357003o. The results of an initial legal analysis of the Agreement have been presented in: Anna Khvorostiankina. "EU-Armenia Comprehensive and Enhanced Partnership Agreement: What Does It Mean for the Armenian Legal System?," Armenian Journal of Political Science 2 (2017): 5-30.

38 Art. 116 (3) of the Armenian Constitution prescribes that international treaties contradicting it may not be ratified. The Constitutional Court, prior to the ratification of an international treaty, determines the compliance of the commitments enshrined therein with the Constitution. DCC-14O7 of 16 March 2017 "On the Case of Conformity of the Obligations Stipulated by the Comprehensive and Enhanced Partnership Agreement between the Republic of Armenia, of the One Part, and the European Union and the European Atomic Energy Community and Their Member States, of the Other Part, signed in Brussels on 24 November 2017 with the Constitution of the Republic of Armenia" (in Armenian), accessed June 15, 2018, http:// concourt.am/armenian/decisions/common/2018/pdf/sdv-1407.pdf.

40 See: Law of the Republic of Armenia on the Comprehensive and Enhanced Partnership Agreement Between the European Union and the European Atomic Energy Community and Their Member States, of the One Part, and the Republic of Armenia, of the Other Part, 11 April 2018 (in Armenian), accessed May 27, 2018, http://www.parliament.am/legislation. php?sel=show\&ID=6399\&lang=arm. 
pending ratification by all EU Member States. ${ }^{42}$ However, starting from June 1, 2018, it has been provisionally applied by the Parties..$^{43}$

The Agreement aims, in particular, "to enhance the comprehensive political and economic partnership and cooperation between the Parties, based on common values and close links, including by increasing the participation of the Republic of Armenia in policies, programmes, and agencies of the European Union," 44 replacing the outdated EU-Armenia Partnership and Cooperation Agreement (PCA) signed in $1996 .{ }^{45}$ It is expected that CEPA "will strengthen [EU-Armenia] cooperation in many different fields such as energy, transport and environment, and lead to increased mobility" and will "lead to an improved business environment and to new opportunities in trade and investments." 46

From the EU's perspective, CEPA objectives belong to Common Foreign and Security Policy, Common Commercial Policy, and development cooperation. Consequently, the legal basis of the Agreement was defined as the combination of Article 37 TEU, Article 207 TFEU (agreements related to Common Commercial Policy), and Article 209 TFEU (agreements in the area of development cooperation), read in

42 In accordance with Art. 385(2), CEPA shall enter into force on the first day of the second month following the date of deposit of the last instrument of ratification or approval.

43 Delegation of the European Union to Armenia, "Step Forward for EU-Armenia Relations as New Agreement is Provisionally Applied," accessed June 1, 2018, https://eeas.europa.eu/ delegations/armenia/45736/step-forward-eu-armenia-relations-new-agreement-provisionallyapplied_en. The provisional application is enabled by Art. 385(5) of CEPA.

Art. 1(a) CEPA. Furthermore, according to Art. 1, CEPA aims to: enhance the comprehensive political and economic partnership and cooperation between the EU and Armenia; strengthen the framework for political dialogue; contribute to the strengthening of democracy and of political, economic and institutional stability in Armenia; to promote, preserve and strengthen peace and stability at both regional and international levels, including through joining efforts to eliminate sources of tension, enhancing border security, and promoting cross-border cooperation and good neighbourly relations; enhance cooperation in the area of freedom, security and justice with the aim of reinforcing the rule of law and respect for human rights and fundamental freedoms; enhance mobility and people-to-people contacts; support Armenia's efforts to develop its economic potential via international cooperation, including through the approximation of its legislation to the EU acquis; establish enhanced trade cooperation allowing for sustained regulatory cooperation in relevant areas and the conditions for increasingly close cooperation in other areas of mutual interest.

45 Art. 380 CEPA.

46 Remarks by High Representative/Vice-President Federica Mogherini following the signing of the European Union-Armenia Comprehensive and Enhanced Partnership Agreement (CEPA) with Edward Nalbandian, Minister of Foreign Affairs of Armenia, Brussels, November 24, 2017, accessed November 26, 2017, https://eeas.europa.eu/delegations/armenia/36208/remarks-hrvpfederica-mogherini-following-signing-european-union-armenia-comprehensive-and_en. 
conjunction with the procedural provisions of Article 218(6)(a) TFEU and the second sub paragraph of Article 218(8) TFEU. ${ }^{47}$

In 2017, the new "soft" law document-EU-Armenia Partnership Priorities48 replacing the ENP Action Plan of 2006 - was adopted to facilitate the implementation of the Agreement. The Priorities will "shape the agenda for regular political dialogue meetings and sectoral dialogues" 49 based on CEPA.

After Armenia's forced "U-turn" towards membership in the Russia-led Eurasian Economic Union (following the Eurasian Customs Union) in September 2013 and the failure of the EU-Armenia Association Agreement, CEPA introduced a new stage in EU-Armenia relations. The Agreement established the legal basis of a new format of partnership. For the EU, the newly signed agreement has become "the first of its kind, as it is concluded with a partner country which is at the same time a member of the Eurasian Economic Union and in the Eastern Partnership." 50 From this perspective, CEPA is a unique legal instrument: it is significantly more elaborate and comprehensive than PCAs of the gos and new agreements with former Soviet states of Central Asia; in some aspects, it resembles Association Agreements concluded with Georgia, Moldova and Ukraine, diverging from them only in parts affected by Armenia's participation in the EAEU. ${ }^{51}$ Arguably, the Agreement became a result of the interplay of Armenia's

47 Joint Proposal for a Council Decision on the Conclusion, on behalf of the European Union, of the Comprehensive and Enhanced Partnership Agreement Between the European Union and the European Atomic Energy Community and their Member States, of the One Part, and the Republic of Armenia, of the Other Part, JOIN/2017/o37 final2017/o238 (NLE), accessed June 17, 2018, https://eur-lex.europa.eu/legal-content/EN/ TXT/?qid=152319357003o\&uri=CELEX:52017JC oo37. The Agreement does not aim to develop association relations (Art. 217 TFEU); instead, it establishes "a specific institutional framework by organising cooperation procedures" (Art. 218 (6)(a)).

48 European Union and Armenia Sign Partnership Priorities, Bruxelles, 21/o2/2018-14:17, UNIQUE ID: 180221_5, accessed March 1, 2018, https://eeas.europa.eu/headquarters/headquartershomepage/40181/european-union-and-armenia-sign-partnership-priorities_en. Partnership Priorities include (1) strengthening institutions and good governance; (2) economic development and market opportunities; (3) connectivity, energy efficiency, environment and climate action; and (4) mobility and people-to-people contacts.

49 Recommendation No. $1 / 2017$ of the EU-Armenia Cooperation Council of 20 November 2017 on the EU-Armenia Partnership Priorities [2018/315], OJ L 6o (March 2, 2018), 51-55, accessed March 15, 2018, http://eur-lex.europa.eu/legal-content/EN/ TXT/?qid=1522643453339\&uri=CELEX:22018Do315.

$5^{\circ}$ Remarks by High Representative/Vice-President Federica Mogherini following the signing of the European Union-Armenia Comprehensive and Enhanced Partnership Agreement (CEPA).

$5^{1} \quad$ This is relevant, first of all, for the "economic" part of the Agreement which - in contrast with the Association Agreements — does not presuppose establishment of the Deep and Comprehensive Free Trade Area; the "political" part of CEPA is based on the draft EU-Armenia Association Agreement (see Hrant Kostanyan and Richard Giragosian, "EU-Armenian 
"complementarity" approach in its multi-vectored foreign policy, on the one hand, and the EU's differentiation and greater flexibility approach within the revised $\mathrm{EaP}$, on the other hand. ${ }^{52}$

The institutional framework of the EU-Armenia partnership resembles (with some exceptions) the institutional frameworks established under AAs and is significantly more advanced in comparison to the institutional framework under the EU-Armenia PCA. It includes: a Partnership Council consisting of representatives of the Parties at a ministerial level, ${ }^{53}$ a Partnership Committee composed of representatives of the Parties, in principle at the senior official level, ${ }^{54}$ sub-committees, ${ }^{55}$ other bodies assisting the Partnership Committee, ${ }^{56}$ a Partnership Parliamentary Committee consisting of members of the European Parliament and the National Assembly of the RA, ${ }^{57}$ and Civil Society Platforms established to enable the active involvement of civil society in the implementation of CEPA. ${ }^{58}$ Importantly, in contrast with the PCA and similar to Association Agreements, CEPA entitles its institutions (the Partnership Council and Partnership Commission) to make binding decisions.

For an in-depth analysis of CEPA's transformative potential, it is important to take into account the social and political context of its ratification and implementation. The ratification of CEPA by the Armenian Parliament coincided with the beginning of peaceful protests and acts of civil disobedience against oligarchy, the monopolization and concentration of power, violations of fundamental rights, the disrespect of the

Relations: Charting a Fresh Course," CEPS Research Report No. 2017-14, November 2017, 12. Available at SSRN: https://ssrn.com/abstract=3075166). Noteworthy, the "political" part (Art. 5(1)) acknowledges Armenia's participation in "international organisations and cooperation formats" in the area of foreign and security policy (which include, in particular, the Russia-led Collective Security Treaty Organization).

See ENP Review (Joint Communication to the European Parliament, the Council, The European Economic and Social Committee and the Committee of the Regions. Review of the European Neighbourhood Policy, 18.11.2015JOIN (2015) 5o final, accessed March 1, 2018, http:// eeas.europa.eu/archives/docs/enp/documents/2015/151118_joint-communication_review-ofthe-enp_en.pdf).

Art. 362 CEPA. Following the beginning of the provisional application of CEPA on June 1, 2018, the first Partnership Council chaired by F. Mogherini took place on June 21, 2018 (Joint Press Statement Following the First Partnership Council Meeting Between the European Union and Armenia, accessed June 22, 2018, http://www. consilium.europa.eu/en/press/pressreleases/2018/o6/21/joint-press-statement-following-the-first-partnership-council-meetingbetween-the-european-union-and-armenia/). Art. 363 CEPA. For example, the Sub-Committee on Customs (Art. 126) and the Sub-Committee on Geographical Indications (Art. 240).

56 Art. 364 CEPA.

57 Art. 365 CEPA.

58 Art. 366 (2) CEPA. 
rule of law, corruption, and other negative phenomena associated with the rule of the Armenian Republican Party and its leader Serzh Sargsyan. Having served for two terms as President of Armenia (2008-2018), on 17 April 2018 Sargsyan was elected Prime Minister by the Parliament. After the constitutional reform of 2015 that introduced the parliamentary system of government and significantly strengthened the authority of the Prime Minister, having made the position of the President a symbolic one, this election meant, in fact, a third presidential term for Sargsyan. As a result of the protests he resigned on 23 April 2018. Opposition leader Nikol Pashinyan was elected Prime Minister of Armenia and formed the new Government.

The new Government immediately started implementing anti-corruption measures and introduced reforms directed at the establishment of the rule of law and good governance. Although the process of a peaceful transition of power did not have any geopolitical connotations and regional integration vectors were not under question, the dynamics of the initiated reforms created the grounds for cautious optimism concerning the potential deepening of EU-Armenia relations. Being in harmony with so-called EU "common" values, these genuinely internal political processes of reform (in conjunction with the active development of civil society) are expected to facilitate the proper implementation of CEPA. Moreover, the demand for successful models and best practices for the "restart" of legal, political, and economic reforms can stimulate the further Europeanization of Armenia even beyond the formal commitments under the Agreement.

\section{The Implementation of CEPA and the Axiological Core of the Armenian Constitutional Order}

In this section I analyze CEPA values and the mechanisms of their promotion. I then compare these values with the Armenian "constitutional identity" as an axiological core of a domestic constitutional order comprising the identity of the Constitution, that of the people and the actual society. On the basis of this comparison, I evaluate the potential effectiveness of CEPA in values promotion.

As the Court of Justice of the European Union (CJEU) has recently noted on several occasions that,

EU law is [...] based on the fundamental premise that each Member State shares with all the other Member States, and recognises that they share with it, a set of common values on which the EU is founded, as stated in Article 2 TEU. That premise implies and justifies the existence of mutual trust between the Member States that those values will be recognised, and therefore that the law of the EU that implements them will be respected"59 (italics added.-A. Kh.). 
The so-called "shared" or "common" values of the European Union thus constitute the cornerstone of the European legal order. In accordance with Art. 2 TEU, they include "respect for human dignity, freedom, democracy, equality, the rule of law, and respect for human rights, including the rights of persons belonging to minorities. These values are common to Member States in a society in which pluralism, non-discrimination, tolerance, justice, solidarity and equality between women and men prevail."

The said values are also to be upheld and promoted in the relations of the EU with the wider world (Art. 3(5) TEU); they serve as a foundation of a "special relationship with neighbouring countries, aiming to establish an area of prosperity and good neighbourliness" (Art. 8(1) TEU). The fundamental values are further reflected in the "principles" of EU external actions (Art. 21(1)).

The concept of "common" or "shared" values is used in the context of the ENP and is specifically underlined in the new agreements with EaP countries. ${ }^{60}$ In the same manner as AAs, CEPA contains several references to "common values." They can be found, in particular, in the recital stating that the Agreement takes account of the values the Parties "share"; in Art. 1 establishing the objectives of CEPA, in particular, to enhance comprehensive partnership and cooperation based on "common values"; in Art. 5 stating that cooperation in the area of foreign and security policy shall be based on "common values and mutual interests." Furthermore, there are numerous provisions referring to specific EU values.

According to S. Poli, there are four main ways the EU uses to promote its values through external action: (1) considering them as "essential elements" of legally binding agreements with partner countries and associating a non-execution clause in case of breach; (2) encouraging third countries to ratify and implement legally binding multilateral agreements based on universal values; (3) making the values a prerequisite for receiving financial assistance from the EU (in particular, within the European Neighbourhood Instrument) and (4) applying sanctions in case of the failure to respect democracy. ${ }^{61}$

An analysis of CEPA reveals that the Agreement employs the first three ways of values promotion identified above. ${ }^{62}$ However, the third way should be viewed more broadly than in the classification provided by Poli: it should be defined as making the implementation of values a prerequisite within the conditionality mechanisms (the incentives of these mechanisms obviously cannot be restricted to the receiving of financial assistance ${ }^{63}$ ). Similarly to the AAs with Georgia, Moldova, and Ukraine, CEPA

case-law cited therein).

See "European Neighbourhood Policy," Strategy Paper COM (2004), 373 final.

61 Sara Poli, "Introduction," in The European Neighbourhood Policy_Values and Principles, edited by Sara Poli (Abingdon, Oxon; New York, NY: Routledge, 2016), 2.

62 The second way can be illustrated, in particular, with Art. 6 CEPA stressing the values of peace and international justice and requiring ratification and implementation of the Rome Statute of the International Criminal Court and its related instruments.

63 Although conditionality based on the "financial assistance" incentive can also be found in CEPA: see Art. 344 stating that the amount of financial assistance provided by the EU to 
employs two types of conditionality: "common values" conditionality and "market access" conditionality, ${ }^{64}$ which serve to export EU values in the former case, and the EU acquis (as a set of rules) in the latter case. ${ }^{65}$

Noteworthy, all four ways may be characterized as purely legal instruments and defined as different variations of conditionality (positive and negative). Departing from a purely legal analysis and applying a socio-legal approach, one can complement these conditionality mechanisms with the mechanisms of "socialization" proposed in Political Science and presupposing that the EU "teaches" domestic actors "the principles and rules of European governance." 66

Art. 2 of CEPA sets forth the fundamental principles of the Agreement. Some of these principles (namely, respect for democratic principles, the rule of law, ${ }^{67}$ human rights, and fundamental freedoms ${ }^{68}$ ) constitute one of the essential elements of the

Armenia "shall take into account the Republic of Armenia's needs, sector capacities and progress with reforms, in particular in areas covered by this Agreement" (italics added).

64 See: Roman Petrov, Guillaume Van der Loo, and Peter Van Elsuwege, "The EU-Ukraine Association Agreement: A New Legal Instrument of Integration Without Membership?," KyivMohyla Law and Politics Journal 1 (2015): 12-13, https://doi.org/10.18523/kmlpj52678.2015-1.1-19; Roman Petrov, "EU Values in Integration-oriented Agreements with Ukraine, Moldova and Georgia," in The European Neighbourhood Policy — Values and Principles, edited by Sara Poli (Abingdon, Oxon; New York, NY: Routledge, 2016).

65 For a detailed description of differences in the methodologies of the export of values and rules see: Dimitry Kochenov, “The Issue of Values," in Legislative Approximation and Application of EU Law in the Eastern Neighbourhood of the European Union, edited by Roman Petrov and Peter Van Elsuwege (London; New York: Routledge, 2014).

66 Frank Schimmelfennig, "Europeanization beyond Europe," Living Reviews in European Governance 7.1 (2012): 8, accessed June 25, 2018, http://www.livingreviews.org/lreg-2012-1.

67 The rule of law is further stressed in Art. 12 CEPA as a basis for the cooperation of the Parties in the areas of freedom, security, and justice. Under this article, the consolidation of the rule of law includes "the independence of the judiciary, access to justice, the right to a fair trial as provided for by the European Convention on Human Rights, and procedural safeguards in criminal matters and victims' rights."

68 Art. 2(1) of CEPA provisions contains an extensive and open-ended list of international instruments in the field of human rights and fundamental freedoms (of both binding "hard" law and non-binding "soft" law nature) in which, according to the Agreement, the Parties must adhere to in their domestic and external policies. The issue of human rights and fundamental freedoms as a prerequisite of a conditionality mechanism can be additionally extracted from other provisions of the "political part": Art. ${ }_{5}$ CEPA obliges the Parties to fully implement Visa Facilitation and Readmission Agreements. In case of fulfilment of these obligations and provided that conditions for well-managed and secure mobility are in place, the Parties shall consider in due course the opening of a visa-liberalisation dialogue. Taking into account the experience of EaP associated countries, the visa liberalization dialogue will focus on, in addition to security benchmarks, benchmarks related to fundamental rights ("Visa Liberalisation with Moldova, 
Agreement ${ }^{69}$; others (the principles of a free-market economy, sustainable development, regional cooperation and effective multilateralism, good governance, and respect for international obligations etc.) are not included in the essential element clause, but are vital for relations under the Agreement and can be viewed as elements of CEPA's conditionality mechanisms.

Arguably, essential element clauses in combination with a non-fulfillment clause $^{70}$ and preamble references to the Parties' commitments constitute one of the mechanisms of value conditionality. It presupposes that all other provisions of CEPA (including provisions on economic cooperation and trade relations) can effectively operate and be implemented only if the specific principles and values are respected by the Parties. Therefore, the values and principles included in the essential elements may be considered as the axiological core of the Agreement.

What is the link between this core and the Armenian "constitutional identity"? Let us consider the constitutional text first. The fundamental values of the rule of law, democracy, and respect for human rights promoted by CEPA are embodied in the unamendable provisions of Articles 1, 2, and 3 of the Armenian Constitution. Consequently, they constitute the basis of its "identity." In a number of its judgements, the Constitutional Court has provided an interpretation of these principles. Of particular interest is the Decision concerning compliance of the EAEU Treaty with the Armenian Constitution, where the Court introduced the concept of the "axiology of the Constitution" covering the values and fundamental principles of the constitutional order, ${ }^{71}$ including, in particular, the rule of law, respect for human rights and democracy. The Court examined (although in a very superficial and formalistic way) and confirmed the compliance of the "axiology" of the commitments under the Treaty with Armenian constitutional "axiology." Arguably, this analysis aimed to enhance the legitimacy of joining a supranational organization which, on the one hand, can potentially limit national sovereignty and, on the other hand, is not committed to strengthening the

Ukraine, and Georgia," accessed March 15, 2018, https://ec.europa.eu/home-affairs/what-wedo/policies/international-affairs/eastern-partnership/visa-liberalisation-moldova-ukraine-andgeorgia_en). Thus, the perspectives of visa liberalization offered in CEPA can also serve as a stimulus for the proper implementation of "common" values in this area.

69 One more essential element is included in Art. 9 and deals with the weapons of mass destruction, non-proliferation, and disarmament. This essential element is standard for EU agreements with third countries. As Cremona observes, WMD clauses have been included in such instruments since 2003 (Marise Cremona, "The ENP and Multilateralism," in The European Neighbourhood Policy — Values and Principles, edited by Sara Poli (Abingdon, Oxon; New York, NY: Routledge, 2016), 85-86). Similar "essential elements" can be found, in particular, in AAs with Georgia, Moldova, and Ukraine (Art. 10 EU-Georgia AA; Art. 9 EU-Moldova AA; Art. 11 EUUkraine AA).

70 Art. 379 CEPA.

71 See: Decision DCC-1175 of 14 November 2014. 
fundamental constitutional values of respect for human rights, democracy, and the rule of law. ${ }^{72}$

In contrast with this Decision, in the Decision on CEPA an analysis of the issue of values is scarce. The Court merely reproduced the provisions of Art. 2 of the Agreement with a focus on the "essential element" clause ${ }^{73}$ and underlined that, according to the Preamble of the Constitution, Armenia alleges universal values. ${ }^{74}$ The Court does not link these two statements and does not highlight the "shared" nature of the axiological core of the Armenian constitutional order and the legal values promoted by the EU. ${ }^{75}$ Arguably, the establishment of this link and the underlining of the commonality of values would have facilitated judicial reference to EU law for the purposes of the interpretation of such values (in particular, to rapidly developing case-law and soft law concerning the rule of law principle in Central Europe).

Regardless of their recognition in the Constitution, the proper implementation of the rule of law, democracy, and respect for human rights as required by CEPA is still a problematic issue. As stated above, such proper implementation can only be possible

Being an organization of economic cooperation, the EAEU does not merely aim at promoting the mentioned values; instead, among the principles of its functioning, the EAEU Treaty lists the respect of the universally recognized principles of international law including the principle of the sovereign equality of member states and "respect of particularities of the political order of the member states" (Art. 3 EAEU Treaty). At the same time, although formally EAEU Member States recognize "European" (or universal) values in their constitutions (see Art. 1 and Art. 2 of the Constitution of the Republic of Belarus; Art. 1 of the Constitution of the Republic of Kazakhstan; Art. 1 of the Constitution of the Kyrgyz Republic; Art. 1 and Art. 2 of the Constitution of the Russian Federation), the implementation of these values is an extremely problematic issue. All of the listed states are either consolidated authoritarian or semiauthoritarian regimes, not free or partly free (based on the data of Freedom House 2018. See: https://freedomhouse.org/report/freedom-world/freedom-world-2018, accessed July 31, 2018). Para. 7 of Decision DCC-1407.

74 Para. 14 of Decision DCC-1407.

75 This lack of theoretical framing of the Decision on CEPA (in contrast to, for example, Decisions on ECHR and ECHR case-law in the domestic legal system, on the constitutionality of the EAEU Treaty and Customs Code) can be better explained through the agency approach: such theoretical (or even philosophical) concepts as "the spirit of the Constitution," "constitutional axiology," "constitutional culture," as well as frequent reference to international standards of fundamental rights in argumentation patterns can be individually attributed to then President of the Constitutional Court Dr. G. Harutyunyan. The examination of his scholarly publications allows for tracing the influence of his theoretical and argumentative approaches on the Court's case-law. The Decision on CEPA was adopted just after the retirement of Dr. Harutyunyan in March 2018 and before the appointment of the new President of the Court. As a consequence, the legal positions of the Court appeared to be rather technical and based on a literal comparison of the obligations under the Agreement and the Constitution. This conclusion is also confirmed by interview data (May 2018). 
when these values are internalized by society. Otherwise, the introduced Europeanization reforms risk retaining a formal, façade character or may even lead to "pathologies of Europeanization," whereby Europeanization processes are instrumentalized by domestic actors and empower incumbent authoritarian governments against their political opponents. ${ }^{76}$ Both situations were typical for Armenia before the change of government in April-May 2018. Currently, Prime Minister Pashinyan underlines that democracy is viewed as a "firm belief," and not as a "geopolitical orientation," and that the aim of the government is to conduct effective legal and political reforms with or without the participation of the EU - which are viewed as essential for the development of the state. ${ }^{77}$

Indeed, the results of observing recent political, legal, and social developments in Armenia allow for concluding that the process of the internalization of fundamental values is in progress (although the influence of the authoritarian Soviet past is still not overcome completely, ${ }^{78}$ and traditional institutions still influence legal and political practices). The government is actively taking steps to transform the constitutional declarations of fundamental values into operating legal provisions. ${ }^{79}$ What was defined

76 Tanja A. Börzel and Yasemin Pamuk, "Pathologies of Europeanization: Fighting Corruption in the Southern Caucasus," West European Politics 35.1 (2011): 79-97. Tanja A. Börzel and Yasemin Pamuk, “Europeanization Subverted? The European Union's Promotion of Good Governance and the Fight Against Corruption in the South Caucasus," KFG Working Paper No. 26 (April 2011), accessed May 1, 2018, http://userpage.fu-berlin.de/kfgeu/kfgwp/wpseries/ WorkingPaperKFG_26.pdf.

77 The statement was made at a press-conference devoted to the results of an official visit to Brussels, on July 12, 2018, and was provoked by Pashinyan's disappointment with EU policy towards Armenia: in his words, regardless of the high appraisals and warm welcoming of the outcomes of the peaceful protests and the reforms already introduced by the new government, the approach of the EU to Armenia in practical terms has not changed (Official web-site of Prime Minister, video of the press-conference. http://www. primeminister.am/hy/videos/ item/9MrD 1Vs-FoA/, i n Armenian, accessed July 14, 2018).

78 Simon Payaslian, The Political Economy of Human Rights in Armenia: Authoritarianism and Democracy in a Former Soviet Republic (London: I. B. Tauris, 2011), 290-93.

79 The change of approach to fundamental constitutional values can also be noticed on the level of political discourse. Comparing the Programs of government activities, one may notice that the Government under the rule of the Republican Party stressed the necessity of creating "the legal basis ensuring the efficiency of public administration in the parliamentary system, the authorities' responsibility and accountability to the public, and the rule of law" and focused mainly on legislative and institutional reforms (see the sections "Vision and Goals of the RA Government Program" and 1.3. "Human Rights Protection, Justice, and the Fight Against Corruption" of the Program of the Government of the RA for 2017-2022 Approved by the Decision of the Government of the RA No 646-A of June 19, 2017, accessed July 1, 2018, http:// www.gov.am/files/docs/2219.pdf). Pashinyan's Government underlines that in the area of the said constitutional values and principles there is no legislative gap but the problem was with 
in scholarship as a necessity for democratic transition in Armenia - the "dissolving of oligarchic economic and political structures" and the "reconfiguration of relations" between the state, individuals, and civil society ${ }^{80}$ - is currently in the focus of government activities ${ }^{81}$ and is being gradually achieved. ${ }^{82}$

In these circumstances, CEPA's "socialization" mechanisms (in particular in the form of "dialogues" and "exchanges of information" on various issues between the Parties, including dialogues with civil society) can facilitate the transformative influence of CEPA on the "constitutional identity" of the actual society.

As regards the geopolitical orientation as a component of the constitutional identity, it should be noted that the Armenian Constitution does not stipulate any restriction on the issue of international or regional cooperation. In contrast with some other post-Soviet countries, it neither indicates any specific integration priorities or preferences. ${ }^{83}$ Armenian foreign policy is based on the principle of "complementarity" and multi-vectored regional cooperation. ${ }^{84}$ As a result, Armenia is currently both a

the political will of the authorities to properly implement them (see section 5.1 "Equality

Before the Law, Justice and Human Rights Protection" of the Program of the Government of RA for 2018 Approved by the Decision of Government N 581-A of June 1, 2018, accessed July 1, 2018, http://www.gov.am/files/docs/2782.pdf).

80 See: Payaslian, The Political Economy of Human Rights in Armenia, 293.

81 See the Program of the Government of the RA for 2018 Approved by the Decision of Government N 581-A of June 1, 2018.

82 The former is achieved through the active implementation of anti-corruption measures and the investigation of corruption-related crimes. The latter - through the strengthening of the rule of law (of particular importance is the initiation of an investigation of Human Rights violations in the period of the Republic Party's rule, including the violent suppression of peaceful protests against electoral fraud in March 2008. At the time of writing, criminal charges were filed against the highest officials, including then President R. Kocharyan, who was charged with "overthrowing the constitutional order in Armenia" see: Radio Freedom, "Kocharian Charged Over 2008 Crackdown," accessed July 26, 2018, https://www.azatutyun. am/a/29392588.html); and other (sometimes unusual) methods of building trust and achieving transparency (e.g. the Prime Minister's regular on-line streams and direct communication with people through social media).

83 See: Decision DCC-1175 of November 14, 2014 in the Case on Conformity of the Obligations Stipulated in the "Treaty on the Accession to the Treaty of May 29, 2014 On The Eurasian Economic Union Signed by the Republic of Armenia" Signed on October 10, 2014 in Minsk with the Constitution of the Republic of Armenia, English version http://concourt.am/english/ decisions/common/pdf/1175.pdf.

84 The Program of the previous Government highlighted deepening bilateral cooperation, in particular, with Russia, the USA, European counties, Georgia, Iran, China, India, countries of the Middle East, and multilateral cooperation with the EAEU, the CSTO, the EU, the CIS, the UN, NATO, and the CoE (see section 2.1 of the Program of the Government of the RA for 2017-2022 approved by the Decision of the Government of the RA No. 646-A of June 19, 2017, 
member of the Russia-led EAEU and has enhanced relations with the EU. However, from the "constitutional identity" perspective, these two regional integration vectors have different characteristics: while the former is forced by Russia's leverage, is based on pragmatic economic interests and security considerations, ${ }^{85}$ and does not aim at any value-based systemic change, ${ }^{86}$ the latter initially (under the rule of the Republican Party) corresponded to domestic demand for modernization on the basis of EU templates ${ }^{87}$ and had a significant value-based discourse component (although not translated into realities, ${ }^{88}$ and was often used as an easy way for Armenian authorities to

accessed July 1, 2018, http://www. gov.am/files/docs/2219.pdf). The same directions of foreign relations are indicated in the Program of Pashinyan's Government. However, noteworthy is (1) stressing the necessity to increase the effectiveness of participation in the EAEU, (2) identifying the principles of cooperation with Russia, in particular, equality; underlying that military cooperation with Russia is an important component of the system of national security; (3) in relations with the EU, focusing on implementation of CEPA and setting the aim to start a dialogue on visa liberalization (see section 3.2 of the Program of Government of the RA for 2018 approved by the Decision of Government No. 581-A of June 1, 2018, accessed July 1, 2018, http://www. gov.am/files/docs/2782.pdf).

85 On Russia's leverage see: Laure Delcour and Kataryna Wolczuk, "The EU's Unexpected 'Ideal Neighbour'? The Perplexing Case of Armenia's Europeanisation," Journal of European Integration 37.4 (2015): 495 .

86 Among basic principles, Art. 3 EAEU Treaty lists the "respect for specific features of the political structures of the Member States," therefore EAEU is formally "indifferent" to the value systems of the member states.

87 Delcour and Wolczuk, “The EU's Unexpected 'Ideal Neighbour'?, 499. It should be noted that before April 2018 this "demand" was of a rather pragmatic nature, aimed mainly at sectoral reforms and - as Delcour and Wolczuk point out in relation to the period of 2009-2013 — was caused by the necessity to decrease the vulnerability of the incumbent government (Delcour and Wolczuk, “The EU's Unexpected 'Ideal Neighbour'?," 498-99). The result was technical legislative reforms that did not bring any systemic change (i. e. overcoming corruption, dissolving oligarchic informal monopolies, introducing good governance. and improving democratic institutions etc.). In fact, it was a case of, providing support at "low political cost" and not endangering the "survival strategy" of the authorities, cooperation with the EU actually prolonged the rule of the authoritarian government (see: Sieglinde Gstöhl, "Differentiated Integration and the NEC," in Legislative Approximation and Application of EU Law in the Eastern Neighbourhood of the European Union, edited by Peter Van Elsuwege and Roman Petrov (London; New York: Routledge, 2014), 102). Currently, cooperation with the EU may be viewed as seeking support for domestic reforms genuinely aiming to bring systemic legal and political change.

88 As Ghazaryan and Hakobyan note, this was due to the lack of rigour of the EU in pursuing the "value conditionality" and the formalistic approach of the Armenian authorities in fulfilling its obligations in this regard (Ghazaryan and Hakobyan, "Legislative Approximation and Application of EU Law in Armenia," 214). 
get EU support at "low political cost" 89 ). Currently, as part of a "shared values" discourse, cooperation with the EU may be viewed as coinciding with the government's vision of further development of the constitutional order.

Noteworthy, the value-based core of the constitutional order may also formally create obstacles for the proper implementation of CEPA. In particular, the Agreement states that " $[\mathrm{t}]$ he Parties shall aim to enhance cooperation in promoting peace and international justice by ratifying and implementing the Rome Statute of the International Criminal Court and its related instruments, and taking into account their legal and constitutional frameworks." ${ }^{90}$ However, in its Decision of 2004, ${ }^{91}$ the Constitutional Court held that the ICC Statute contradicts the Constitution. The reasoning of the Court was based on two arguments: (1) the absence of the right to be pardoned or amnestied in the Statute, restricting the scope of rights guaranteed by the Constitution, ${ }^{92}$ and (2) the impossibility to complement or modify the national judicial system through international treaties derived from the principle of sovereignty. ${ }^{93}$ The Court underlined that ratification of the Statute would only be possible in case of introducing amendments to the Constitution. Nevertheless, neither the constitutional amendments of 2005 nor the reform of 2015 enabled the ratification. ${ }^{94}$

In this specific case, "constitutional identity" as a value-based core of a constitutional order - through the constitutional principle of sovereignty — is clearly intertwined with constitutional identity as the level of the "openness" of the domestic legal order to external influences.

\section{5. "Constitutional Identity" as the "Openness" of the Domestic Constitutional Order and Legal Approximation Under CEPA}

This section of the article focuses on the interrelation of the level of openness of the legal order to external influences and the effectiveness of legal approximation ${ }^{95}$ under

89 Gstöhl, "Differentiated Integration and the NEC."

90 Art. 6(2) CEPA.

91 Decision DCC-502 of 13 August 2004 on the compliance of obligations under the Statute of the International Criminal Court (Annexed Declaration) signed on July 17, 1998 in Rome with the Constitution of the RA.

Then Art. 40 and 81 of the Constitution of the RA.

93 Then Art. 91 and 92 of the Constitution of the RA.

94 The Concept Paper on the Constitutional Reform of 2015, however, stated that constitutional reform "must create the preconditions for ratification" of the Rome Statute of the ICC (see para. 2.6.4 of The Concept Paper on the Constitutional Reform Elaborated by the Specialized Commission on Constitutional Reforms Adjunct to the President of the RA (draft of September 2, 2014), accessed June 1, 2018, http://www. venice.coe.int/webforms/documents/default. aspx?pdffile=CDL-REF(2014)o33-e). Nevertheless, the wording of the constitutional norms that the Constitutional Court defined as being in conflict with the Statute, remain the same.

The term "legal approximation" is used to describe the comprehensive transformation of a legal order. In addition to "legislative approximation" to the EU acquis, it covers the absorption of 
CEPA. As defined above, the level of openness indicates the capacity to absorb legal norms and rules, as well as practices and methodological approaches through formal and informal channels.

According to the Constitution of Armenia, CEPA as an international treaty ratified by the National Assembly, enjoys supremacy over national legislation ${ }^{96}$ (but not over the Constitution). This constitutional provision serves as the main formal channel of interaction between the Agreement and the domestic legal order. However, being complex in nature, in order to achieve its goals CEPA requires more sophisticated mechanisms of interaction based on a combination of formal and informal channels and tools. In particular, these mechanisms should allow for the operation of decisions of CEPA institutions, the implementation of the Agreement's provisions concerning legislative approximation, and provisions focusing on general legal principles (in terms of both law-making and law enforcement), as well as enable the Armenian judiciary to contribute to CEPA's proper implementation.

In addition to the existence of such mechanisms "opening" the domestic legal order to CEPA influence, the effectiveness of the implementation of CEPA will also depend on how open (formally and informally) the Armenian legal order will be towards the concurring project of regional integration - the Russia-led EAEU. Although the new Agreement takes "full account of Armenia's obligations as a member of the Eurasian Economic Union," ${ }^{97}$ this, however, does not exclude the possibility of potential conflicts between EAEU norms and provisions of CEPA, specifically in the areas covered by both CEPA and the EAEU Treaty. ${ }^{98}$ One of the reasons for these potential conflicts may be rooted in the "immanent weaknesses" of the EAEU legal framework.99

the legal principles, methodological approaches, and legal practices necessary for the proper implementation of the approximated legislation.

96 Art. 5 of the Constitution of the RA.

97 Joint Proposal for a Council Decision on the Signing, on Behalf of the European Union, and Provisional Application of the Comprehensive and Enhanced Partnership Agreement Between the European Union and the European Atomic Energy Community and their Member States, of the One Part, and the Republic of Armenia, of the Other Part, September 25, 2017, JOIN/2017/o36 final—2017/o236 (NLE), accessed June 17, 2017, http://eur-lex.europa.eu/legalcontent/EN/TXT/?qid=1511682870752\&uri=CELEX:52017JC oо36.

98 Notably, in the course of negotiations "to ensure that the values underpinning CEPA remain firm," the EU rejected a "carve-out clause" proposed by the Armenian side, which would allow Armenia "to opt out of the commitments enshrined in CEPA in areas where the Eurasian Economic Union might make new provisions" (Kostanyan and Giragosian, "EU-Armenian Relations: Charting a Fresh Course," referring to the interview with an EU official (Brussels, September 5, 2016), 7).

99 Among such specific features of the EAEU Treaty Dragneva, Delcour and Jovanicius identify: "the mixture between current and future commitments, the problematic institutional boundaries between the members' commitments and delegated powers, and the prevalence of power relations within a highly asymmetric hub-and-spoke context." (Rilka Dragneva, Laure Delcour and Laurynas Jovanicius, “Assessing Legal and Political Compatibility between 


\subsection{Decisions of CEPA Institutions and the Domestic Constitutional Framework}

There are two categories of binding decisions of CEPA institutions:

(1) the decisions of the Council by which Annexes to CEPA will be updated to take into consideration the development of EU legislation for the purposes of legislative approximation ${ }^{100}$; and

(2) other decisions of CEPA institutions.

For both types of decisions Armenian constitutional law excludes direct applicability and establishes specific requirements. Implementation of the decisions of the first type presupposes the ratification of amendments to Annexes in the same manner as the Agreement itself is ratified,101 including the preliminary control of constitutionality by the Constitutional Court. Reviewing CEPA, the Court did not analyze the content of the Annexes and the compatibility of the specific acquis with the Armenian Constitution. Presumably, in case of amending the Annexes, the Court will also formally review only the obligation to approximate and will leave it to legislators to resolve the substantive issue of transposition first (with the possibility of constitutional control of approximated national law a posteriori).

As regards the second type of decisions, currently Armenian legislation does not define their legal status and the implementation procedure and does not provide the possibility of the direct effect of acts adopted by CEPA institutions. Noteworthy, the implementation of acts of the Eurasian Economic Commission has been recently regulated in a specific provision of the Law "On Normative Legal Acts." ${ }^{102}$ In contrast to the previous Law "On International Agreements," which regulated the implementation of acts adopted by international organizations (that could arguably have been applied by analogy in the case of CEPA), the new Law "On International Agreements" 103 is silent in this regard.

In the absence of legislative regulation, certain guidelines concerning the interaction of binding decisions of CEPA institutions with the domestic legal order can be found in the case-law of the Constitutional Court. In particular, in the Decision concerning the constitutionality of the EAEU Treaty, ${ }^{104}$ the Court has formulated

European Union Engagement Strategies and Membership of the Eurasian Economic Treaty,"

EU-STRAT Working Paper 2 (2017): 12).

100 Art. 371 CEPA

101 See Decision of the Constitutional Court DCC-1407, par. 11.

102 Law of the RA HO-18o-N “On Normative Legal Acts" of March 21, 2018 in Art. 24 prescribes that in case the Eurasian Economic Commission adopts an act the subject matter of which belongs to the areas of regulation by law in Armenia, the Government should exercise legislative initiative and introduce the relevant implementing draft law to the Parliament. In all other cases, the Government adopts an act giving effect to the act of the Commission.

103 Law of the RA HO-213-N “On International Agreements” of March 23, 2018.

104 Decision DCC-1175 of 14 November 2014. 
several legal positions, arguably applicable to such decisions by analogy. The Court pointed out that the acts of any international or supranational organization should be in accordance with the principles of sovereignty, ${ }^{105}$ the legal equality of the Parties, and the mutual expediency of international cooperation. Furthermore, restrictions on human rights [possibly resulting from participation in a supranational organization] should be in accordance with the norms and principles of international law. The Court also stressed that the operation of decisions of supranational bodies in Armenia is possible only within the scope of accordance with the Constitution. ${ }^{106}$ The Court held that "any decision adopted by any supranational body with the participation of the Republic of Armenia, which is not in conformity with these requirements, is not applicable in the Republic of Armenia. In the case of following these requirements, the cooperation of Armenia with any international or regional organization will not raise the issue of constitutionality." 107

Apparently, to guarantee legal certainty and to ensure the effectiveness of the implementation of the Agreement, the domestic legislative framework should clearly define the status and regulate the procedural issues of the operation of acts of CEPA institutions in the Armenian legal order.

\subsection{CEPA Mechanisms of Legislative Approximation}

The mechanisms of legislative approximation employed in CEPA resemble the mechanisms of the AAs, although are less advanced and ambitious due to CEPA's more modest objectives. At the same time, in contrast with the EU-Armenia PCA containing only one general and legally non-binding approximation clause, ${ }^{108}$ CEPA's

105 From the point of view of constitutional identity, the concept of sovereignty is of particular importance. The Case-law of the Constitutional Court indicates that "sovereignty" includes the possibility of its "sharing" on the basis of a voluntary decision of the Republic of Armenia. In particular, deciding on the issue of the jurisdiction of the ECHR and the binding force of its judgements for Armenia, the Court stated that, although the Constitution does not directly provide the right to apply to the international courts to protect one's rights, "taking as a ground the authorizing nature of Article 43 of the Constitution of the Republic of Armenia and the sovereign right of the Republic of Armenia voluntary and on the basis of mutual concordance to accept such an obligation in the name of the effectiveness of the international co-operation, it can be noted that the obligations set forth by Articles 36 and 43 of the Convention do not contradict the spirit of the Constitution of the Republic of Armenia" (para. 14 of the Decision DCC-350 of 22 February 2002 On Conformity of Obligations Stated in the Convention for the Protection of Human Rights and Fundamental Freedoms [...] with the Constitution of the RA, English version available at: http://concourt.am/english/decisions/common/doc/sdv-35oe.htm, accessed March 15, 2018; italics added).

106 Para. 7 of Decision DCC-1175 of 14 November 2014.

107 Para. 7 of Decision DCC-1175 of 14 November 2014.

108 Art. 43 of PCA. 
approximation mechanisms are significantly more elaborate, diverse, and framed with provisions of a binding nature. ${ }^{109}$

Furthermore, alongside the establishment of advanced approximation mechanisms, in contrast with the PCA, CEPA underlines the importance of the implementation and enforcement of the approximated legislation and establishes specific mechanisms for the monitoring and assessment of approximation. ${ }^{110}$ This novelty is similar to the approach of the AAs and may be considered a reaction to the shortcomings of previous approximation attempts. ${ }^{111}$

The obligation of Armenia to "carry out gradual approximation of its legislation to EU law as referred to in the Annexes" (with exceptions for specific provisions under Title VI ${ }^{112}$ ) is set forth in Art. 370 of CEPA. This general provision is supplemented with provisions containing standard approximation clauses in eight chapters of Title $\mathrm{V}$ (Other Cooperation Policies) and Title VII (Financial Assistance, and Anti-Fraud and Control Provisions) of the Agreement. ${ }^{113}$ The Annexes linked to these clauses indicate the EU legislative acts Armenia "undertakes to gradually approximate its legislation to" and the timeframes for such approximation.114 They do not lead to an opening of the market but can be elements of other conditionality mechanisms.

The lists of EU legislation contain regulations, directives (including implementing regulations and directives) and international acts and shall be periodically revised

109 Although the degree of bindingness of different provisions varies.

110 See, in particular, Preamble and Art. 372 CEPA.

111 It should be noted that legislative approximation to the EU acquis is not a new phenomenon for the Armenian legal system. Some efforts of approximation were made under the PCA ENP Action Plan and in course of the negotiations concerning the failed AA and DCFTA. However, regardless of some achievements (see, for example, Delcour and Wolczuk, "The EU's Unexpected 'Ideal Neighbour'?," 491-507), this process can generally hardly be defined as successful, as it lacked coherence, a systematic approach, and common methodological ground. The implementation of the approximated legislation was particularly problematic. For example, Ghazaryan and Hakobyan report on the active and extensive approximation of Armenian competition law in the framework of the ENP and achieving compliance with the EU dynamic acquis (Ghazaryan and Hakobyan, "Legislative Approximation and Application of EU Law in Armenia," 201). However, the formal compliance of domestic legislation with the dynamic EU competition acquis in no way touched upon the problem of politically supported artificial oligarchic monopolies, therefore not affecting in practice the economic environment of the country.

112 Trade and Trade-Related Matters.

113 These are: Article 41 with Annex I (transport), Art. 44 with Annex II (energy), Art. 50 with Annex III (environment), Art. 56 with Annex IV (climate), Art. 65 with Annex V (information society), Art. 83 with Annex VI (consumer protection), Art. 90 with Annex VII (employment, social policy and equal opportunities), Art. 361 with Annex XII (anti-fraud regulations). In some cases, the timeframes are not precisely indicated but are to be defined by the Partnership Council. 
by the Partnership Council "in order, inter alia, to reflect the evolution of EU law and applicable standards set out in international instruments deemed relevant by the Parties, taking into account the completion of the Parties' respective internal procedures" (Art. 371).

In addition to this approximation mechanism ("standard approximation clause + the lists of the EU legislation and the specified timeframes"), there are also a number of provisions containing a general requirement to approximate Armenian legislation with the the EU acquis without specification of relevant EU acts and the timeframes of approximation. The formulation and binding character of such requirements, as well as the expected degree of approximation/convergence vary. According to Art. 169, 180, and 192 of Title VI "Trade and Trade-Related Matters," which are key elements of the conditionality mechanisms relevant to the liberalization of a cross-border supply of services, ${ }^{115}$ "parties recognise the importance of gradual approximation" of Armenian legislation on postal services, electronic commerce, and transport services to that of the EU. According to Art. 189, "the Republic of Armenia shall approximate its regulation of financial services, as appropriate, to the legislation of the European Union." Art. 130 dealing with cooperation in the field of technical barriers to trade states that "the Parties shall endeavour to establish and maintain a process through which gradual approximation of the technical regulations, standards and conformity assessment procedures of the Republic of Armenia to those of the European Union can be achieved." In accordance with Art. 81 related to consumer protection, the parties "shall cooperate in order to ensure a high level of consumer protection and to achieve compatibility between their systems of consumer protection." Art. 70 states that the Parties "shall cooperate to promote agricultural and rural development, in particular through progressive convergence of policies and legislation." Furthermore, there are a number of "soft" provisions employing "taking into account" and "making efforts" formulas.

One more approximation mechanism can be found in the provisions requiring the implementation of international instruments and compliance with international standards promoted by the EU. These commitments are either general (referring to international or European standards generally) or specifically defined (referring to specific international acts to be implemented).

Other areas of cooperation ${ }^{116}$ do not presuppose legislative approximation. However, the Armenian legal system may benefit from the improvement of national legislation in these areas through the exchange of information and best practices with the EU, which can serve as informal channels of the transposition of the EU acquis into the domestic legal order.

115 According to Art. 373 CEPA, "If the Parties agree that necessary measures covered by Title VI have been implemented and are being enforced, the Partnership Council, [...] shall decide on further market opening where provided for in Title VI." 
Importantly, legislative approximation can be done on a voluntary basis and can go beyond the formal requirements of CEPA. The scope of such voluntary approximation will apparently depend on the political will of the decision-makers to choose EU regulatory approaches as models for domestic reforms, as well as on the level of influence (both formal and informal) of the EAEU in the relevant sectors of regulation.

To achieve more effective interaction between the EU and Armenian legal orders through approximation processes, it is important to develop an institutional mechanism and a methodological framework of approximation, both of which are missing at the time of writing. ${ }^{117}$ What is also lacking is an effective academia-policy dialogue on issues of the further development of the Armenian legal system, which could serve as an informal channel of Europeanization.

\subsection{The Transposition of General Legal Principles of EU Law}

In addition to the legislative approximation requirements in specific sectors, a number of provisions of CEPA are directed at the improvement of legislative regulation in Armenia generally. These provisions reflect general principles of EU law, such as the predictability of legal regulation, legal certainty, the quality of regulation, good governance etc. ${ }^{118}$

Undoubtedly, these provisions - even when they formally concern a specific sector of bilateral cooperation - have the potential to positively influence the development of the Armenian legal system as a whole. Similarly to fundamental values, the principles listed above are not unknown in the Armenian legal order and formally find their reflection in domestic legislation (their proper implementation, however, requires both the improvement of legislatives techniques and the establishment and maintenance of high standards of administrative and judicial procedures). The highlighting of the abovementioned general principles in CEPA can potentially stimulate and justify the reference to the EU acquis for the purposes of their interpretation.

\subsection{The Role of the Judiciary 5.4.1. The Role of CJEU}

Importantly, legislative approximation mechanisms established by the abovementioned Articles 169, 180, 189, and 192 presuppose a specific procedure of dispute settlement by an arbitration panel. In particular, "where a dispute raises a question of interpretation of

At the time of writing national programs of the implementation of CEPA generally, and of legislative approximation in particular, were not elaborated. There are several institutions involved in the process of approximation (e. g. the Parliamentary Standing Committee on European Integration, the "Centre for Legislation Development and Legal Research" Foundation in the MoJ, relevant departments in the ministries and other governmentt agencies); however, the institutional mechanism is not coherent and well-coordinated. 
a provision of Union law, the arbitration panel shall request the [CJEU] to give a ruling on the question provided that question is necessary for the decision of the arbitration panel. [...] The ruling [of the CJEU] shall be binding on the arbitration panel." 119

Similar mechanisms can be found in the AAs with EaP countries ${ }^{120}$; they are called upon to ensure the uniform interpretation of the EU acquis in relations with third countries. ${ }^{121}$ Arguably, this mechanism will also serve as a formal "channel" for absorbing CJEU case-law by the domestic legal order.

\subsubsection{The Role of Domestic Courts}

CEPA's focus on the implementation and enforcement of the approximated legislation indicates the significant role of the judiciary in the process of the Europeanization of the Armenian legal system. The main mission of the judiciary is, therefore, to properly apply national legislation adhering to the fundamental principles of the administration of justice. In some cases, however, such proper implementation may demand taking into account the EU acquis, including CJEU case-law, for the purposes of the interpretation of national legislation (although it is not required by CEPA ${ }^{122}$ ).

Arguably, the following obstacles will affect such application:

(1) the nature of legal approximation commitments under CEPA, the absence of a clear EU-oriented vector of foreign policy, and the presence of the concurring EAEU integration project limiting the possibility of judicial activism; ${ }^{123}$

(2) inaccessibility of CJEU case-law due to the linguistic barrier, a lack of awareness of relevant decisions and skills using search tools; ${ }^{124}$

119 Art. 342 (2) CEPA.

120 However, in contrast with CEPA, these provisions contain lists of EU acts to be transposed.

121 Guillaume Van der Loo, “The EU-Ukraine DCFTA," in Legislative Approximation and Application of EU Law in the Eastern Neighbourhood of the European Union, edited by Peter Van Elsuwege and Roman Petrov (London; New York: Routledge, 2014), 82.

122 And, consequently, there is no domestic legislation providing a formal "channel" for such application (in contrast with the case-law of the ECHR, recognized as an official source of law by Art. 15 of the Judicial Code of the RA).

123 This is in contrast with the situation in Central and East European countries where explicit orientation towards EU and related domestic policy choices, clear membership perspectives, and stricter obligations to harmonize national legislation with the EU acquis created favourable grounds for judicial activism and led to the establishment of the practice of an "EU-friendly" interpretation of domestic legislation (see Kühn “The Application of European Law," 566-68).

124 University curricula usually cover only the fundamentals of EU law and are not oriented towards skills-training. There is also a lack of scholarly studies on the issues in question as well as a lack of a dialogue between academia and practitioners serving as an informal channel of Europeanization. Among recent developments in this field one can mention the establishment of the Laboratory of Legal Approximation (Center for Interdisciplinary Legal Studies, UNESCO Chair on Human Rights, Democracy and Political Science, Yerevan Brusov State University 
(3) the lack of a coherent theory and the practice of judicial argumentation based on up-to-date methodological approaches, due to the long-lasting dominance of legal positivism, generally, ${ }^{125}$ and the lack of experience in using the EU acquis in argumentation in particular. ${ }^{126}$

of Languages and Social Sciences) focusing on the research and training on legislative approximation methodology and analysis of CJEU case-law.

This problem is common for many post-communist legal systems. See, for example: Kühn, "The Application of European Law"; Meleshevych and Khvorostyankina, "Ukraine," 563-64.

126 One of the rare examples of the application of the EU acquis alongside the norms of international law is the decision of the court of general jurisdiction of the administrative district of Kentron and Norq-Marash of Yerevan (first instance) of April 3, 2015 in case EKD/1929/o2/13 I. Avagyan v. "Prometey Bank" on the recognition of the arbitration clauses of the loan agreements as invalid. The court refers to the Convention on the Recognition and Enforcement of Foreign Arbitral Awards (1958) and, additionally, states that "recent Directives of the European Union require Member States to create alternative dispute resolution mechanisms in a range of areas such as banking and financial services [...]. The Republic of Armenia undertook the obligation to establish the alternative dispute resolution procedure in accordance with international law"; then the Court mentions PCA, the inclusion of Armenia in ENP in 2004, and states that under the ENP Action Plan Armenia has also been obliged to create arbitration procedures in compliance with international standards. The Court notes that the principles of out-of-court dispute resolution were enshrined in the Recommendation of the European Commission 1998/257/EC. In the following sections, the Court refers to ECHR case-law. Noteworthy, this argumentative passage is literally reproduced from the defendant's response to the plaintiff's claim reported in the descriptive part of the judgment. In a number of cases - civil (concerning financial services) and administrative (issues of migration law and asylum), of first and appellate instances - the judgements contain references to the EU acquis (directives and soft-law) only in the descriptive parts reflecting the positions of the parties. Although the courts themselves do not refer to these sources in motivation parts, such references can informally influence the further development of judicial argumentation in the future, providing judges with samples of argumentative patterns. The Constitutional Court is reluctant to refer to the EU acquis as well (in contrast with the law of the ECHR and other acts of the CoE). The analysis of relevant judgments shows that there is no coherent practice of referring to such sources. The references to the the EU acquis (comprising EU soft law and CJEU case-law) occur in supportive arguments (which by themselves are used only occasionally when arguments based on national legislation and binding international acts are lacking or not strong enough) and are rather exceptions than a well-established argumentative approach (see cases DCC-991, DCC-1051, DCC-1244). While examining foreign legal materials in the course of preparing advisory opinions on cases, the Legal Advisory Service of the Court has not usually covered the EU acquis as focusing mainly on the constitutional regulations and practice of individual European countries (based on the data of interviews with experts of the Service). 
Taking this into account, using the EU acquis in judicial argumentation could be facilitated through certain legislative drafting techniques. In particular, preambular references to relevant EU acts in the approximated domestic legislation could serve as grounds for using both these acts and case-law, interpreting them to construct arguments based on purposive and "legislator's intent" approaches. ${ }^{127}$ This would be particularly helpful taking into account the gradual and, in some cases, partial nature of legislative approximation: the indication of the actual scope of approximation by the legislator would determine the legitimacy and relevance of using CJEU case-law in domestic judicial argumentation.

\section{Conclusion}

The analysis of the transformative potential of the newly signed EU-Armenia CEPA through the prism of the "constitutional identity" concept allows for making the following conclusions. The "axiological core" of the Armenian Constitution is formally in harmony with that of CEPA; however, the translation of fundamental values into legal and political societal practices has been a problematic issue for a long time. The disharmony between formally declared values and the constructed constitutional identity of an imagined political community, on the one hand, and their reflection in the real life of a society, on the other hand, is a result of different dynamics of change within the legal, political, and sociological dimensions of constitutional identity. This should be taken into consideration to achieve the goals of the Agreement.

The recent peaceful transition of power in Armenia in April-May 2018 created a specific environment for CEPA's implementation. Previously, ruling elites frequently underlined their commitment to adhere to European values, in both domestic and international discourses. However, the reality of implementing these values in practice significantly differed from what was declared, and introduced reforms often represented a façade change. The incumbent government, to the contrary, tends to avoid references to the "Europeanness" of the supported constitutional values in its political discourse, underlining the genuinely domestic character of current political developments. At the same time, the initiated reforms aim to bring real systemic change. Reforms being coherently implemented and procedurally in compliance with fundamental constitutional values can undoubtedly create a favorable environment for CEPA's implementation.

127 The possibility of including a preamble into the structure of a legislative act "to define the objectives and reasons" of its adoption derives from Art. 13(1) of Law of the RA HO-18o-N "On Normative Legal Acts" of March 21, 2018. The said legislative technique is used, for example, in Moldova (see Anna Khvorostiankina, "Legislative Approximation and Application of EU Law in Moldova," in Legislative Approximation and Application of EU Law in the Eastern Neighbourhood of the European Union, edited by Roman Petrov and Peter Van Elsuwege (London; New York: Routledge, 2014), 168). 
At the same time, an analysis of the state of the "openness" of the domestic legal order to interaction with the EU reveals that proper implementation of the Agreement can be hindered by several factors. First, at the moment, a comprehensive legislative framework for CEPA's implementation is lacking (in particular, the status of decisions of CEPA institutions and institutional and methodological aspects of legislative approximation need clear regulation). Second, Armenia's participation in the EAEU and a certain openness of the legal order to its influences creates the possibility of potential conflicts between the processes of Europeanization and Eurasian integration. Third, the judiciary, which is expected to be the main channel of absorbing European norms and principles and the guarantor of the proper implementation of the approximated legislation, needs to acquire new knowledge and to develop relevant skills and methodological approaches. This is caused, in particular, by the necessity to take into consideration the case-law of the CJEU. Even though there is no such requirement in CEPA (in contrast to the AAs and some other EU external agreements), this may be essential for the proper interpretation and implementation of "Europeanized" legislation.

The transformative capacity of the Agreement, consequently, depends on the ability of the Armenian legal order to overcome the said obstacles. Proper implementation of the approximated legislation in accordance with CEPA provisions requiring legal certainty and predictability, regulatory quality, the transparency of regulation, good administrative behavior etc. will surely contribute to further improvement of the Armenian legal system. Apparently, this may be achieved only under the circumstances of a comprehensive and systematic government approach to the implementation of the required reforms and the further socialization of domestic actors facilitating the internalization of "shared" values.

\section{Bibliography}

Avbelj, Matej. "Pluralism and Systemic Defiance in the EU." In The Enforcement of EU Law and Values: Ensuring Member States' Compliance, edited by Andras Jakab and Dimitry Kochenov, 44-64. Oxford: Oxford University Press, 2017.

Börzel, Tanja A., and Yasemin Pamuk. "Europeanization Subverted? The European Union's Promotion of Good Governance and the Fight Against Corruption in the South Caucasus." KFG Working Paper No. 26 (April 2011). http://userpage.fu-berlin. de/kfgeu/kfgwp/wpseries/WorkingPaperKFG_26. pdf.

Börzel, Tanja A., and Yasemin Pamuk. "Pathologies of Europeanization: Fighting Corruption in the Southern Caucasus." West European Politics 35.1 (2011): 79-97.

Cloots, Elke. "National Identity, Constitutional Identity, and Sovereignty in the EU." Netherlands Journal of Legal Philosophy 2.45 (2016): 82-98.

Cotterrell, Roger. Law, Culture and Society: Legal Ideas in the Mirror of Social Theory. London: Routledge, 2006. 
Cremona, Marise. "The ENP and Multilateralism." In The European Neighbourhood Policy — Values and Principles, edited by Sara Poli, 81-98. Abingdon, Oxon; New York, NY: Routledge, 2016.

Delcour, Laure, and Kataryna Wolczuk. “The EU's Unexpected 'Ideal Neighbour'? The Perplexing Case of Armenia's Europeanisation." Journal of European Integration 37.4 (2015): 491-507.

Delegation of the European Union to Armenia. "Step Forward for EU-Armenia Relations as New Agreement is Provisionally Applied" (June 1, 2018). Accessed June 1, 2018. https://eeas.europa.eu/delegations/armenia/45736/step-forward-eu-armeniarelations-new-agreement-provisionally-applied_en.

Dragneva, Rilka, Laure Delcour, and Laurynas Jovanicius. “Assessing Legal and Political Compatibility between European Union Engagement Strategies and Membership of the Eurasian Economic Treaty." EU-STRAT Working Paper No. 2 (November 2017).

Faraguna, Pietro. "Constitutional Identity in the EU-A Shield or a Sword?" German Law Journal 18.7 (2017): 1617-40.

Ghazaryan, Narine, and Anna Hakobyan. "Legislative Approximation and Application of EU Law in Armenia." In Legislative Approximation and Application of EU Law in the Eastern Neighbourhood of the European Union, edited by Peter Van Elsuwege and Roman Petrov, 191-214. London: Routledge, 2014.

Ghazaryan, Narine. "A New Generation of Human Rights Clauses? The Case of Association Agreements in the Eastern Neighbourhood." European Law Review $40.3(2015): 391-410$.

Ginsburg, Tom, and Mila Versteeg. "Constitutional Correlates and the Rule of Law." In Constitutionalism and the Rule of Law: Bridging Idealism and Realism, edited by Maurice Adams, Anne Meuwese and Ernst Hirsch Ballin, 506-25. Cambridge; New York: Cambridge University Press, 2017.

Gstöhl, Sieglinde."Differentiated Integration and the NEC." In Legislative Approximation and Application of EU Law in the Eastern Neighbourhood of the European Union, edited by Peter Van Elsuwege and Roman Petrov, 89-107. London; New York: Routledge, 2014 .

Häberle, Peter. "The Constitutional State and Its Reform Requirements." Ratio Juris 13.1 (2000): 77-94. Cited in: Yaniv Roznai, “Towards a Theory of Constitutional Unamendability," Jus Politicum 18 (2017): 5-37. http:/juspoliticum.com/uploads/ jp18-to1_roznai.pdf.

Jacobsohn, Gary Jeffrey. “Constitutional Identity." The Review of Politics 68 (2006):361-97. Khvorostiankina, Anna. "Legislative Approximation and Application of EU Law in Moldova." In Legislative Approximation and Application of EU Law in the Eastern Neighbourhood of the European Union, edited by Roman Petrov and Peter Van Elsuwege, 159-78. London; New York: Routledge, 2014.

Kochenov, Dimitry. "The Issue of Values." In Legislative Approximation and Application of EU Law in the Eastern Neighbourhood of the European Union, edited by Roman Petrov and Peter Van Elsuwege, 46-62. London; New York: Routledge, 2014. 
Kostanyan, Hrant, and Richard Giragosian. "EU-Armenian Relations: Charting a Fresh Course." CEPS Research ReportNo. 2017-14, November 2017. https://ssrn.com/ abstract $=3075166$.

Kühn, Zdeněk. "The Application of European Law in the New Member States: Several (Early) Predictions." German Law Journal 6.3 (2005): 563-82.

Marti, Jose Luis. "Two Different Ideas of Constitutional Identity: Identity of the Constitution v. Identity of the People." In National Constitutional Identity and European Integration, edited by Alejandro Saiz Arnaiz and Carina Alcoberro Llivina, 17-36. Antwerp: Intersentia, 2013.

Mazzone, Jason. “The Creation of a Constitutional Culture." Tulsa Law Review 40.4 (2004): 671-98.

Meleshevych, Andriy, and Anna Khvorostyankina. "Ukraine." In The European Convention on Human Rights and fundamental freedoms in Central and Eastern Europe, edited by Leonard Hammer and Frank Emmert, 557-96. The Hague: Eleven International Publishing, 2012.

Mogherini, Federica. Remarks by High Representative/Vice-President Federica Mogherini Following the Signing of the European Union-Armenia Comprehensive and Enhanced Partnership Agreement (CEPA) with Edward Nalbandian, Minister of Foreign Affairs of Armenia, Brussels, November 24, 2017. Accessed November 26, 2017. https://eeas.europa.eu/delegations/armenia/36208/remarks-hrvp-federicamogherini-following-signing-european-union-armenia-comprehensive-and_en.

Pavone, Tommaso. Constitutional Identity: An Overview and Some Conceptual Concerns, April 23, 2014. https://scholar.princeton.edu/sites/default/files/tpavone/files/ jacobsohn-_constitutional_identity_critical_review.pdf.

Payaslian, Simon. The Political Economy of Human Rights in Armenia:Authoritarianism and Democracy in a Former Soviet Republic. London: I. B. Tauris, 2011.

Petrov, Roman, Guillaume Van der Loo, and Peter Van Elsuwege. "The EU-Ukraine Association Agreement: A New Legal Instrument of Integration Without Membership?" Kyiv-Mohyla Law and Politics Journal 1 (2015): 1-19. https:// doi.org/10.18523/kmlpj52678.2015-1.1-19.

Petrov, Roman. "EU Values in Integration-Oriented Agreements with Ukraine, Moldova and Georgia." In The European Neighbourhood Policy - Values and Principles, edited by Sara Poli, 99-112. Abingdon, Oxon; New York, NY: Routledge, 2016.

Pilsen, Monika."Constitutional Identity, Unconstitutional Amendments and the Idea of Constituent Power: The Development of the Doctrine of Constitutional Identity in German Constitutional Law." I*CON, 14 (2016): 411-38.

Poli, Sara. "Introduction." In The European Neighbourhood Policy-Values and Principles, edited by Sara Poli, 1-8. Abingdon, Oxon; New York, NY: Routledge, 2016.

Prime Minister. Official web-site. Video of press-conference, July 12, 2018. Accessed July 14, 2018. http://www.primeminister.am/hy/videos/item/9MrD iVs-FoA/.

Radaelli, Claudio M. "Whither Europeanization? Concept Stretching and Substantive Change." European Integration Online Papers 4.8 (2000): 1-28. https://ssrn.com/ abstract $=302761$. 
Robertson, David. The Judge as Political Theorist: Contemporary Constitutional Review. Princeton: Princeton University Press, 2010.

Rodina, Anita, and Janis Pleps. "Constitutionalism in Latvia: Reality and Developments.” In New Millennium Constitutionalism: Paradigms of Reality and Challenges, with a foreword of Dr. G. G. Harutyunyan, 431-72. Yerevan: Njhar, 2013.

Rosenfeld, Michel. "Constitutional Identity." In The Oxford Handbook on Comparative Constitutional Law, edited by Michel Rosenfeld and András Sajó, 756-76. Oxford: Oxford University Press, 2012.

Rosenfeld, Michel. "The Constitutional Subject, Its Other, and the Perplexing Quest for an Identity of Its Own: A Reply to My Critics." Cardozo Legal Studies 358 (2012): 1-29. https://ssrn.com/abstract=2021356.

Safjan, Marek. "Political and Constitutional Courts. A Judge's Personal Perspective." EUI Working Paper Law 10 (2008): 1-23. http://cadmus.eui.eu/handle/1814/8101.

Saiz Arnaiz, Alejandro, and Carina Alcoberro Llivina. "Why Constitutional Identity Suddenly Matters: A Tale of Brave States, a Mighty Union and Decline of Sovereignty." In National Constitutional Identity and European Integration, edited by Alejandro Saiz Arnaiz and Carina Alcoberro Llivina, 1-15. Antwerp: Intersentia, 2013 .

Schimmelfennig, Frank. "Europeanization Beyond Europe." Living Reviews in European Governance 7.1 (2012):1-31. Accessed June 25, 2018. http://www.europeangovernancelivingreviews.org/Articles/lreg-2012-1/download/lreg-2012-1Color.pdf.

Siegel, Andrew M. "Constitutional Theory, Constitutional Culture." Journal of Constitutional Law 18.4 (2016): 1067-128.

Śledzińska-Simon, Anna. "Constitutional Identity in $3 \mathrm{D}$ : A Model of Individual, Relational, and Collective Self and its Application in Poland." InternationalJournal of Constitutional Law 13.1 (2015): 124-55. https://doi.org/10.1093/icon/movoo7.

Van der Loo, Guillaume. "The EU-Ukraine DCFTA." In Legislative Approximation and Application of EU Law in the Eastern Neighbourhood of the European Union, edited by Peter Van Elsuwege and Roman Petrov, 63-88. London; New York: Routledge, 2014.

Von Bogdandy Armin, Piotr Bogdanowicz, Iris Canor, Maciej Taborowski, Matthias Schmidt. "A Constitutional Moment for the European Rule of Law-Upcoming Landmark Decisions Concerning Polish Judiciary." MPIL Research Paper Series 10 (2018): 1-13. Accessed June 25, 2018. https://ssrn.com/abstract=31998og.

Von Bogdandy, Armin. "Pluralism, Direct Effect, and the Ultimate Say: On the Relationship Between Iinternational and Domestic Constitutional Law." International Journal of Constitutional Law 6.3-4 (2008): 397-413.

Vorländer, Hans. "Gründung und Geltung: Die Konstitution der Ordnung und die Legitimität der Konstitution.” In Geltungsgeschichten: Über die Stabilisierung und Legitimierung institutioneller Ordnungen, ed. Gert Melville and Hans Vorländer. Cologne; Weimar; Vienna: Böhlau, 2002. Cited in: Silke Hensel, Ulrike Bock, Katrin Dircksen and Hans-Ulrich Thamer, ed., Constitutional Cultures: On the Concept 
and Representation of Constitutions in the Atlantic World. Newcastle upon Tyne: Cambridge Scholars Publishing, 2012.

Žalimas, Dainius. "Eternity Clauses: a Safeguard of Democratic Order and Constitutional Identity." Speech of the President of the Constitutional Court of Lithuania. Accesssed November 1, 2017. http://www. gjk-ks.org/repository/docs/Speech_ of_the_President_of_the_Constitutional_Court_of_Lithuania_Prof.Dr._Dainius_ alimas.pdf.

Anna Khvorostiankina holds a PhD in Legal Theory (Legislation Institute of the Verkhovna Rada of Ukraine, 2012); a Second Level Masters in "Advanced Studies in European and Transnational Law" (University of Trento, Italy, 2006); and a LL. M. degree (NaUKMA, Ukraine 2005). Her research interests include the Europeanization of post-Soviet legal systems, recent developments in the theory and practice of judicial argumentation in post-Soviet countries, and particularities of the Rule of Law in societies in transition. 